\title{
ISOLATION AND IDENTIFICATION OF ARBUSCULAR MYCORRHIZAL FUNGI (AMF) IN CASHEW PLANTS (Anacardium occindentale L.) IN DATAH VILLAGE, ABANG DISTRICT OF KARANGASEM REGENCY
}

\section{Ketut Suada, Evy Prima, Made Sritamin, I Wayan Adiartayasa, I Gede Ketut Susrama, and I Gede Putu Wirawan*}

Faculty of Agriculture, Udayana University

*Corresponding author: igpwirawan@unud.ac.id

\begin{abstract}
Isolation and identification of arbuscular mycorrhizal fungi (AMF) in cashew plants was carried out in Datah Village, Abang District of Karangasem Regency. This study aims to determine the diversity of mycorrhizal spores in the cashew rhizosphere and AMF infections in the roots of cashew plants. The result in microscopic observations found 5 genera of AMF spores such as Glomus, Racocetra, Entrophospora, Septoglomus, and Acaulospora and the population of the genus Glomus were found most dominant in the rhizosphere of cashew plants. The result of staining root with trypan blue obtained the internal structure of AMF in the form of vesicles, arbuscules and hyphae found in root tissue of cashew plants. The result of AMF DNA amplification with primer NS31 and AML2 showed 560 bp bands in electrophoresis with $1 \%$ agarose gel determined AMF infection in root of cashew plants.
\end{abstract}

Keywords: Cashew, Arbuscular Mycorrhizal Fungi, Microscopic, Staining root, PCR

\section{INTRODUCTION}

Cashew (Anacardium occindentale

L.) is one of the commodities that have been known by the people of Indonesia, especially the people of Bali. Cashew is one of Bali's main commodities besides coconut, coffee, and cocoa (Dinas Perkebunan Provinsi Bali, 2013). Based on the statistics of Dinas Perkebunan Provinsi Bali in 2014, the area of cashew plantation in Bali is 12,285 ha with production of $3,498,72$ tons or productivity of $445 \mathrm{~kg}$ / ha. Karangasem regency became the largest cashew production center in Bali with plantation area of 9,480 ha. Karangasem as the center for cashew production is located in three sub-districts with the largest area of cashew plantations are Kubu, Abang, and Karangasem.

Abang sub-district has the largest dry land in Karangasem regency, which is 12,658 ha followed by Kubu, Rendang, and Karangasem sub-districts. Low potential dry land (marginal land) in terms of fertility and low rainfall are mostly found in the subdistricts of Kubu, Abang, and Karangasem (Bappeda Karangasem, 2003). The development of cashew plants in areas with marginal and dry climate conditions show that it is can compete with other plantation crops. However, cashew resilience against drought led to the production of only the range of $2-3 \mathrm{~kg} /$ tree / year. (Trisilawati et al., 2012). 
The existence and use of mycorrhizal fungi as biological tool in agriculture can improve plant growth, productivity and quality without degrading the quality of soil ecosystems. In addition, the application of arbuscular mycorrhizal fungi (AMF) can assist in the rehabilitation of critical land and increase the productivity of agricultural crops, plantations, forestry on marginal lands (Syah et al., 2007). Utilization of arbuscular mycorrhizal fungi (AMF) is one of the ways in the development of cashew plants on critical land. The use of adaptive mycorrhiza to critical and dry land was needed therefore it is necessary to isolate and identify mycorrhizal either microscopically or molecularly on cashew plant in critical and dry land.

This study aims to determine the diversity of mycorrhizal spores in the cashew rhizosphere and AMF infections in the roots of cashew plants.

\section{MATERIALS AND METHODS}

The research was conducted on December 2016 until February 2017. Samples of soil and root of cashew were collected by diagonal sampling at the cashew plantation in Datah Village, Abang district, Karangasem. Analysis of the 2 samples obtained was carried out at the Udayana University's Genetics and Biomolecular Resource Laboratory. AMF spores were isolated from $100 \mathrm{~g}$ soil samples by wet sieving technique and were analyzed under compound microscope. Spore identification was done manually based on INVAM (at http://invam.caf.wvu.edu) in relation to morphological characteristics as shape, size, colour, presence of structures like sporiferous saccule, and subtending hypha.

Internal structure of AMF on root were observed using 25 pieces $(1 \mathrm{~cm})$ of the cashew roots. The roots were subjected to bleaching in a solution of $\mathrm{KOH} 10 \%$ at $100^{\circ} \mathrm{C}$ for $45 \mathrm{~min}$, washed in water and subsequently immersed in $\mathrm{H}_{2} \mathrm{O}_{2} 3 \%$ at $100^{\circ} \mathrm{C}$ for $45 \mathrm{~min}$, washed in water and subsequently immersed in $\mathrm{HCl} 1 \%$ for 30 min, followed by staining in $0.05 \%$ trypan blue for $24 \mathrm{~h}$ thereafter remove the $0.05 \%$ trypan blue then add lactoglycerol heated at $250^{\circ} \mathrm{C}$ for $5 \mathrm{~min}$ and were analyzed under compound microscope. The percentage of root infections by AMF was calculated with the slide method (Brundett et al., 1996). The colored roots were cut into $1 \mathrm{~cm}$ long pieces and arranged in a row of glass preparations 5 roots each sample. Infected root by AMF are known by the structure of AMF (vesicles, arbuscules, and hyphae) on roots.

Analysis infection of AMF in the roots with PCR technique analyzed using primer NS31 and AML2. Approximately $1 \mathrm{~g}$ of roots for each sample were ground in liquid nitrogen with mortar and pestle to break the cell wall and DNA was extracted 
with a Geneaid Genomic DNA Mini Kit (Plant) according to the manufacturer's instructions. Each PCR mixture $(20 \mu \mathrm{l})$ contained $1 \mu$ l DNA, $1 \mu$ l each primer), $5 \mu 1$ PCR master mix solution, and $2 \mu \mathrm{l}$ free water. An initial denaturation for $3 \mathrm{~min}$ at $94^{\circ} \mathrm{C}$ was followed by 30 cycles of $30 \mathrm{sec}$ at $94^{\circ} \mathrm{C}, 1 \mathrm{~min}$ at $40^{\circ} \mathrm{C}$ and $1 \mathrm{~min}$ at $72^{\circ} \mathrm{C}$ and a final extension for $10 \mathrm{~min}$ at $72^{\circ} \mathrm{C}$.

\section{RESULT AND DISCUSSION}

The results of microscopic observation of AMF spores in this study found 5 genera of AMF spores such as Glomus, Racocetra, Entrophospora, Septoglomus, and Acaulospora. The population of Glomus were found most dominant in the cashew rhizosphere. According to Walker et al. (1992 in Warouw and Kainde, 2010) AMF spore populations are high when there are 14-
160 spores / $100 \mathrm{~g}$ of soil. The number of spores obtained in each sample can be seen in the Table 1.

In each sample was found 2-4 different types of the AMF genera. The AMF genera found in sample 1 are 3 genera namely Glomus, Racocetra and Entrophospora. In sample 2 there are 4 genera of spore that are Glomus, Racocetra, Entrophospora and Septoglomus, in sample 3 found 2 genera namely Glomus and Acaulospora, in sample 4 there are 3 genera of AMF that is Glomus, Acaulospora and Septoglomus, and in sample 5 are 2 genera spores that are Glomus and Racocetra. The diversity of the genera of AMF spores found in cashew tree rhizosphere namely Glomus, Racocetra, Entrophospora, Septoglomus, and Acaulospora showed that cashew plants can associate more than one genus of AMF.

Table 1. Number of spores and Genera of AMF in $100 \mathrm{~g}$ Soil Samples

\begin{tabular}{|c|c|c|c|c|c|c|}
\hline \multirow{2}{*}{ Sample } & \multirow{2}{*}{$\begin{array}{c}\text { Total } \\
\text { Spores }\end{array}$} & \multirow{2}{*}{ Genus } & \multirow{2}{*}{$\begin{array}{c}\text { Number of } \\
\text { Spores }\end{array}$} & \multicolumn{3}{|c|}{ Number of Spores } \\
\hline & & & & $212 \mu \mathrm{m}$ & $106 \mu \mathrm{m}$ & $53 \mu \mathrm{m}$ \\
\hline \multirow[t]{3}{*}{ Sample 1} & 61 & Glomus & 38 & - & 25 & 13 \\
\hline & & Racocetra & 20 & 20 & - & - \\
\hline & & Entrophospora & 3 & 3 & - & - \\
\hline \multirow[t]{4}{*}{ Sample 2} & 55 & Glomus & 30 & - & 15 & 15 \\
\hline & & Racocetra & 18 & 18 & - & - \\
\hline & & Entrophospora & 2 & 2 & - & - \\
\hline & & Septoglomus & 5 & 1 & 4 & - \\
\hline \multirow[t]{2}{*}{ Sample 3} & 59 & Glomus & 44 & - & 23 & 21 \\
\hline & & Acaulospora & 15 & - & 15 & - \\
\hline \multirow[t]{3}{*}{ Sample 4} & 46 & Glomus & 32 & - & 18 & 14 \\
\hline & & Acaulospora & 9 & - & 9 & - \\
\hline & & Septoglomus & 5 & 2 & 3 & - \\
\hline \multirow[t]{3}{*}{ Sample 5} & 54 & Glomus & 32 & - & 20 & 12 \\
\hline & & Racocetra & 22 & 22 & - & - \\
\hline & & $\Sigma$ Spores & 275 & 68 & 132 & 75 \\
\hline
\end{tabular}


According to Barker and Weeks (1991 on

Wulandari et al., 2013) site differences and rhizosphere lead to difference in species diversity and population of fungi.

The genus Glomus is the most dominant spore of the AMF on cashew rhizosphere compared to other spores. According to Husin et al. (2007) Glomus spores are found dominant in various rhizosphere in the critical land of Sumatra. Suamba et al. (2014) reported Glomus spores were also found to be dominant in citrus plant rhizosphere in Kerta Village, Payangan
District, Gianyar Regency. According to Brundrett et al. (1996 in Delvian 2010), the genus Glomus has an excellent adaptability to various environmental conditions. One of the advantages of adaptation of the genus Glomus in the environment is the spores germitate faster. Glomus spores only take 4-6 days of germination. Wang and Jiang (2015) report, the dominant number of Glomus spores in the rhizosphere is due to the spores of the genus Glomus can produce more spores compared to other AMF genera in the same environment.
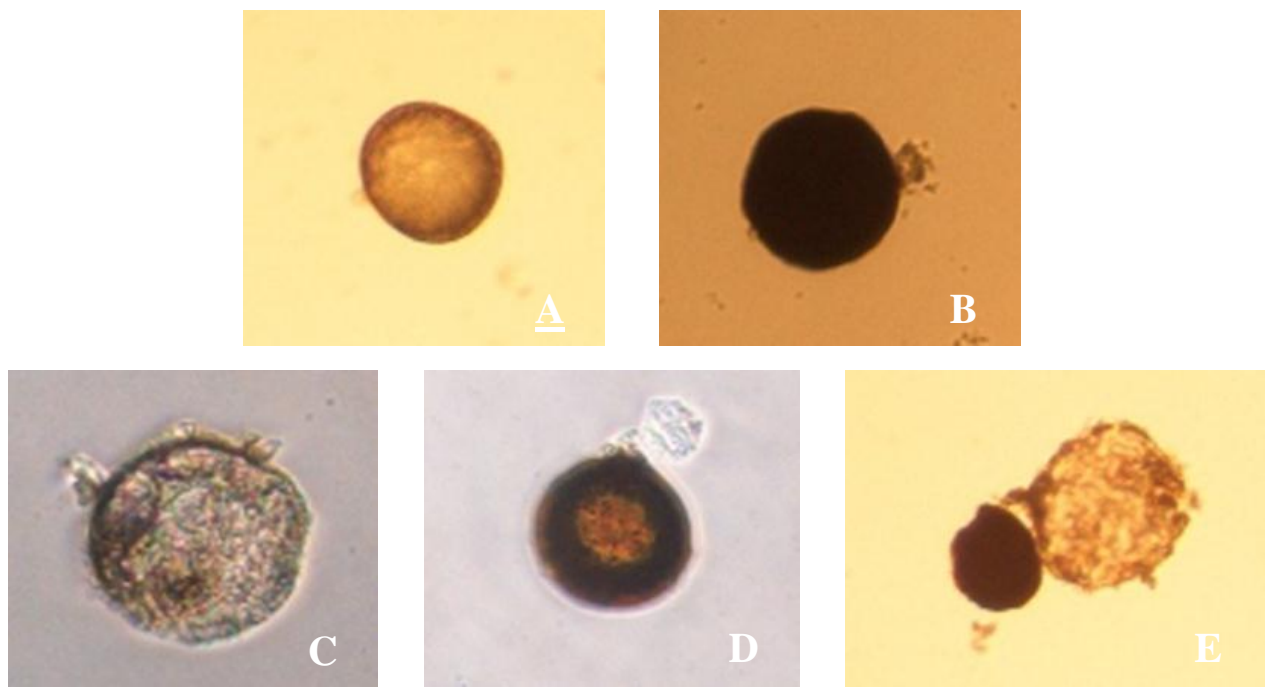

Fig. 1. AMF spores in the cashew tree rhizosphere.

$\mathrm{A}=$ Glomus, $\mathrm{B}=$ Racocetra, $\mathrm{C}=$ Septoglomus, $\mathrm{D}=$ Acaulospora, $\mathrm{E}=$ Entrophospora

The results of microscopic observation on AMF spores in cashew root in this study found that there were infection of AMF on all samples. According to Wulandari et al. (2013), infection of AMF can be known with the presence of the internal structure (hypha, vesicles, and arbuscules) that was formed by AMF. The percentage of root infections by
AMF based on the calculation using the slide method, obtained AMF infection that occurs in the roots of cashew plants is $100 \%$. According to Aldeman et al., (2006)., mycorrhizal infection can increase plant growth and its ability to utilize the nutrients present in the soil, especially $\mathrm{P}, \mathrm{Ca}, \mathrm{N}, \mathrm{Cu}$, $\mathrm{Mn}, \mathrm{K}$, and $\mathrm{Mg}$ elements. Mycorrhizal 
colonization of plant roots can expand the root absorption plane in the presence of external hyphae that grows and develops through roots (Mosse, 2001). The precentage of AMF infection on cashew roots can be seen in the Table 2.

Internal structure of AMF on cashew root in this study found that the vesicles were round, slightly round, oval, and dark blue colored. According to INVAM (2017), vesicles were generally are oblong to elliptical in shape and usually stain darkly in trypan blue or other stain. Arbuscules were found to be shaped as colonization of branched trees on plant root cells. According to INVAM (2017), the shape of the arbuscula may vary within the same root or between roots depending on the homogeneity of stain diffusion and the reactivity to the stain. Arbuscules is a colonizing unit that has reached the deeper cortical cells and penetrates the cell wall to forms a complex hyphae branch system, they usually seen as a small tree with branches (Gunawan, 1993 on Setiadi and Setiawan 2011). Internal hyphae were found shaped as blue thin threads on root tissues . According to INVAM (2017), internal hyphae are commonly found branched or unbranched and interconnected, they usually stain darkly in trypan blue and other stains. Pictures of the internal structure of AMF on cashew roots can be seen in Fig. 2.

According to Smith and Read (2008) the most important structure in a symbiotic system with plant roots is arbuscules. Arbuscules are structures formed by internal hyphae and connect fungi with root cortical cells. This structure plays a role in nutrient traffic from fungi to plants and vice versa. The size of the infection, the development of external hyphae, and the production of spores depend on the environmental conditions of an area.

Tabel 2. Precentage of AMF Infection on Cashew Roots

\begin{tabular}{ccccc}
\hline \multirow{2}{*}{ Sample } & \multicolumn{2}{c}{ Infeksi Struktur Internal AMF (5 potong akar) } & $\begin{array}{c}\text { Infeksi AMF } \\
(\%)\end{array}$ \\
\cline { 2 - 4 } & Vesikula & Arbuskula & Hifa & 100 \\
Sample 1 & 5 & - & 2 & 100 \\
Sample 2 & 5 & - & 5 & 100 \\
Sample 3 & 5 & - & 1 & 100 \\
Sample 4 & 5 & 1 & 2 & 100 \\
Sample 5 & 5 & 1 & 1 & 100 \\
\hline$\Sigma$ & 25 & 2 & 11 & \\
\hline
\end{tabular}


ISOLATION AND IDENTIFICATION OF ARBUSCULAR MYCORRHIZAL FUNGI (AMF) IN CASHEW PLANTS (Anacardium occindentale L.) IN DATAH VILLAGE, ABANG DISTRICT OF KARANGASEM REGENCY I Ketut Suada, Evy Prima, Made Sritamin, I Wayan Adiartayasa, I Gede Ketut Susrama, and I Gede Putu Wirawan

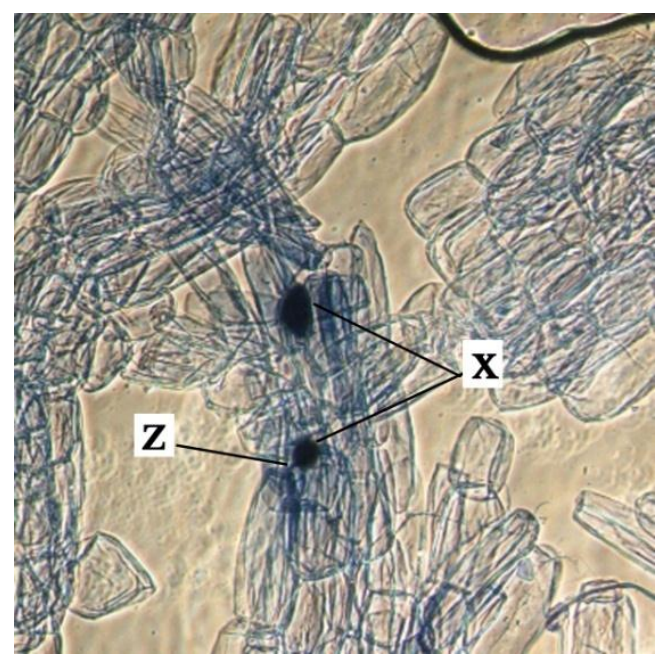

a

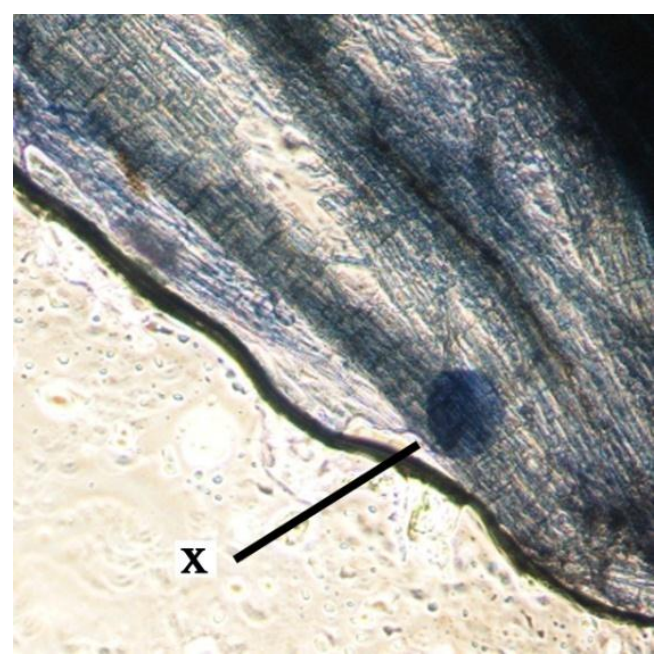

C

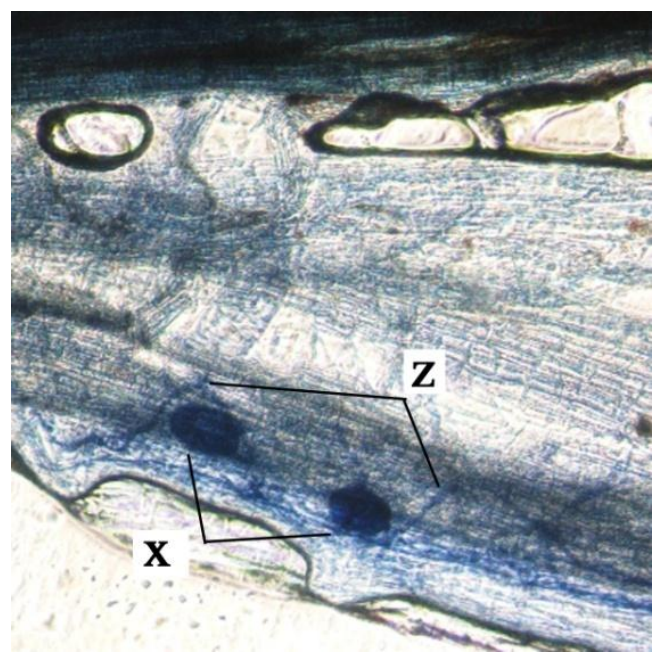

b

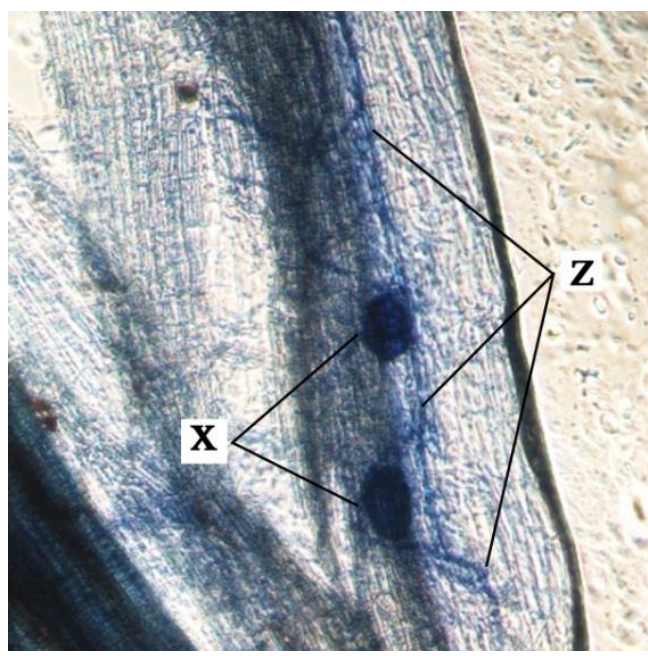

d

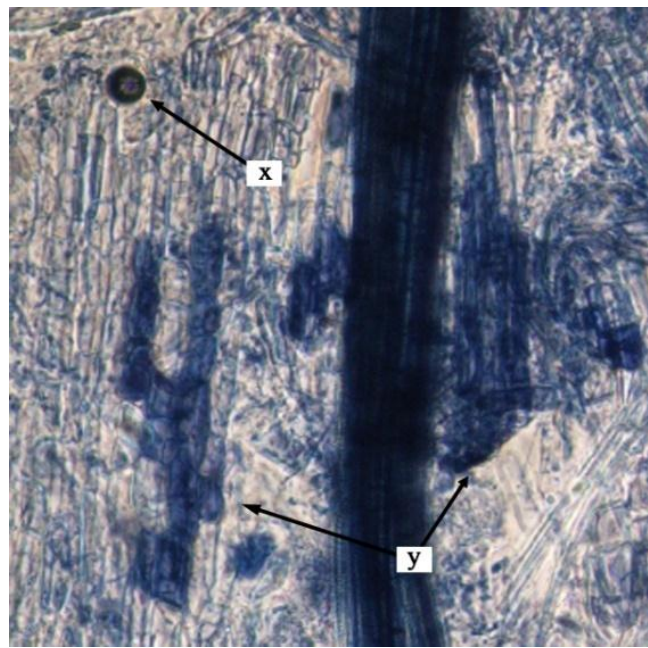

e

Fig. 2. Internal Structure of AMF Structure on Cashew Root. $\mathrm{x}=$ vesicules, $\mathrm{y}=$ arbuscules, dan $\mathrm{z}=$ internal hypha. 
The result of DNA isolation on cashew roots obtained DNA genome. The DNA genome is the entire genetic material found in a plant. The results of DNA genome isolation were electrophoresed on $1 \%$ agarose gel showed that DNA genome on cashew roots were succesfully obtained by the present of DNA bands on the electrophoresis. The obtained DNA genome then further observed by amplify the DNA genome that obtainbed before. The result of amplified DNA then the continued to electrophoresis of $1 \%$ agarose gel. The results of electrophoresis showed the presence of DNA bands in columns 1-5, indicating the presence of AMF infections in all roots of cashew tree samples. While in column K no bands were found because only contain free water. The DNA bands of electrophoresis signifies the AMF DNA reacts positively to the specific primers NS31 and AML2 of AMF and showed the 560bp band. The size of band that obtained in this study was $560 \mathrm{bp}$, which is a fragmental measure for the Glomeromycota gene. Mycorrhizal of Glomeromycota phylum is a group of rhizosphere microorganisms that can symbiosis with at least $80 \%$ of plants that live on land. The latest classification of Glomeromycota has nine families, namely Glomeraceae, Archaespoceae,

Paraglomeraceae, Diversisporaceae, Pacisporaceae, Acaulosporaceae,
Ambisporaceae. The results of amplified DNA electrophoresis can be seen in Fig. 3.

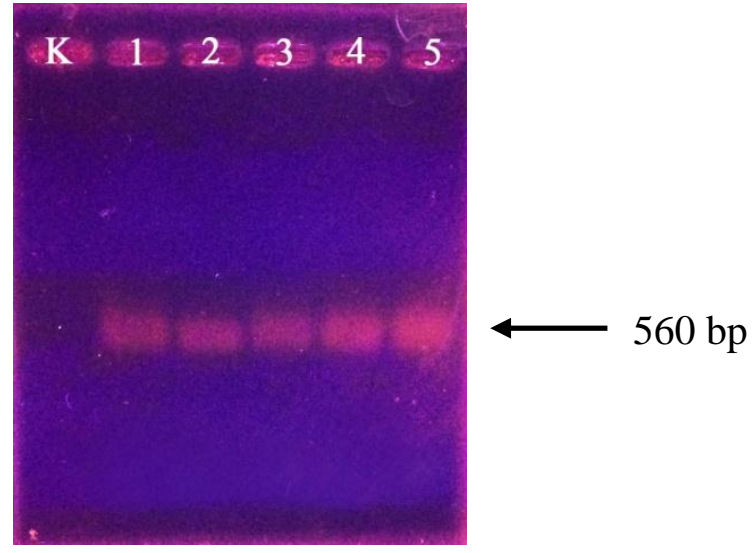

Fig. 3. Electrophoresis of amplified DNA $\mathrm{K}=$ Control, $1=$ Sample 1, $2=$ Sample 2, $3=$ Sample 3, $4=$ Sample 4, $5=$ Sample 5

\section{REFERENCES}

Aldeman, J. M., \& Morton., J. B. (2006). Infectivity of Vesicular Arbuscular Mychorrizal Fungi Influence Host Soil Diluent Combination on MPN Estimates and Percentage Colonization. Journal of Soil Biolchen, 8(1), 77-83.

Brundrett, M., N. Bougher., B. Dell., T. Grove., \& Malajczuk, N. (1996). Working with Mychorrizas in Forestry and Agriculture. ACIAR Monograph : Canberra.

Delvian, (2010). Keberadaan Cendawan Mikoriza Arbuskula (CMA) di Hutan Pantai Berdasarkan Gradien Salinitas. Jurnal Ilmu Dasar, 11(2), 133-142.

Dinas Perkebunan Provinsi Bali. (2013). Komoditi Unggulan. http://www.disbun.baliprov.go.id/komo diti/index/.

Dinas Perkebunan Provinsi Bali. (2014). Statistik Perkebunan Jambu Mete Bali 2014. Luas Areal dan Produksi Perkebunan Jambu Mete di Bali Dirinci Menurut Kabupaten Dan Kebun

Gigasporaceae, Claoroideo-Glomeraceae and 
(PBSN) Tahun 2014. Dinas Trisilawati, O., J. Towaha., \& Daras. U.

Perkebunan Provinsi Bali.

Geneaid. (2015). Genomic DNA Mini Kit (Plant) Ver.07.16.15. http://www.geneaid.com.

Husin, E. F., Marlis, R., Trimitri., Auzan., Burhanuddin., \& Zelfi, Z. (2007). Observasi dan identifikasi spora Cendawan Mikoriza Arbuskula (CMA) pada berbagai rhizosfir di lahan kritis Sumatera. Disajikan pada Seminar Nasional Mikoriza Percepatan Sosialisasi Teknologi Mikoriza untuk Mendukung Revitalisasi Kehutanan, Pertanian dan Perkebunan. Bogor, 19-20 Juli 2007.

INVAM. (2017). International Culture Collection of (Vesicular) Arbuscular Mycorrhizal Fungi. www.invam.wvu.edu.

Mosse, B. (2001). Vesicular-arbuscular Mycorrhizal Research for Tropical. Journal Agriculture. Res. Bull. 82p.

Setiadi, Y., \& Setiawan, A. (2011). Studi Status Fungi Mikoriza Arbuskula di Areal Rehabilitasi Pasca Penambangan Nikel (Studi Kasus PT INCO Tbk. Sorowako, Sulawesi Selatan). Silvikultur Tropika 3(1), 88-95.

Smith, S.E., \& Read. D.J. (2008). Mycorrhizal Symbiosis. 3rd eds. Elseivier. Amsterdam.

Suamba, I. W., Wirawan, I. G. P., \& Adiartayasa, W. (2014). Isolasi dan Identifikasi Fungi Mikoriza Arbuskula (FMA) secara Mikroskopis pada Rhizosfer Tanaman Jeruk (Citrus sp.) di Desa Kerta, Kecamatan Payangan, Kabupaten Gianyar. EJurnal Agroekoteknologi Tropika, 3(4).

Syah, M. J. A., . Muas., I. \& Herizal., Y. (2007). Pemanfaatan Cendawan Mikroza Arbuskula Untuk Memacu Pertumbuhan Bibit Manggis. Tabloid Sinar Tani, 24 Oktober 2007. (2012). Pengaruh Mikoriza dan Pupuk NPK Terhadap Pertumbuhan dan Produksi Jambu Mete Muda. Buletin RISTRI,b3 (1).

Wang, M. \& Jiang, P. (2015). Colonization and Diversity of AM Fungi by Morphological Analysis on Medicinal Plants in Southeast China. The Scientific World Journal, 753842, 7.

Warouw, V., \& Kainde, R. P. (2010). Populasi Jamur Mikoriza Vesikula Arbuskula (MVA) Pada Zona Perakaran Jati. Eugenia, 16(1).

Wulandari, N. L. D., M. Proborini, W., \& Sundra., I. K. (2013). Eksplorasi Spasial Cendawan Tanah Pada Sekitar Rhizosfer Tanaman Jambu Mete (Anacardium Occidentale L.) di Karangasem dan Buleleng-Bali. Jurnal Simbiosis I (2), 85-101. 